\title{
Body composition and somatotype of judo athletes and untrained male students as a reference group for comparison in sport
}

\author{
Krzysztof Buśkoํㅜ, Anna Pastuszak², Ewa Kalka \\ 1 Department of Anatomy and Biomechanics, Kazimierz Wielki University, Bydgoszcz, Poland; 2 Department of \\ Biomechanics, Institute of Sport National Research Institute, Warsaw, Poland; ${ }^{3}$ Institute Mother and Child, Warsaw, \\ Poland
}

\section{Summary}

Study aim: The aim of this study was to determine the body composition and somatotype of untrained male students studying at Warsaw University of Technology in 2011, in order to create a current reference group for comparison, and to investigate the difference in body build of male judoists compared with the non-athlete group.

Materials and methods: Fifteen male judo athletes (age $18.6 \pm 1.9$ years, body height $177.4 \pm 8.5 \mathrm{~cm}$, body mass $80.3 \pm 15.8 \mathrm{~kg}$, training experience $10.0 \pm 2.8$ ) and 154 male untrained students of the Warsaw University of Technology (age $20.1 \pm 0.9$ years, body height $180.9 \pm 7.2 \mathrm{~cm}$, body mass $75.6 \pm 10.9 \mathrm{~kg}$ ) participated in the study. Somatotype was determined using the HeathCarter method.

Results: The mean somatotype of the untrained students was 3.94.62.9, whilst that of the judo athletes was 3.25.91.8; the groups differed significantly in their mesomorphy and ectomorphy components. Significant differences between the groups were found in breadth of wrist, bicristal diameter and arm circumference $(p<0.05)$. The groups were also significantly different in body composition as estimated by BIA and anthropometric methods $(\mathrm{p}<0.05)$.

Conclusion: The morphological characteristics of the judo athletes differed from those of the untrained men. The somatic profile of body build for athletes in this sport seems to be optimal for achieving high results, the somatotype not having changed since the 1990s.

Key words: Male students - New reference group - Body composition - Somatotype - Judo athletes

\section{Introduction}

Specific somatotypes, proper body build proportions, and body composition can determine the success of athletes in respective sports disciplines, e.g. combat sport [26], kayak athletes [6,10], cricket [31], volleyball $[4,10]$ and basketball $[2,10]$, as well as distinguishing those who play different roles in the game $[1,7,11]$. Adapting to exercise, developed during training and the selection process, has resulted in a decrease in somatotype diversity among athletes of similar disciplines, unlike in the non-trained population [29]. The somatotype of athletes is most often compared to the body build of players of the highest level $[10,26]$, or to that of untrained reference groups, such as students [8, 18, 27], or conscripts [19]. The body build of average young adults may usually serve as the point of reference for athletes achieving the highest sports results. Such a reference group are the Polish students at the Warsaw University of Technology, who, among academic youth, have the highest biological indices. Since the early 1950s, these have been examined at intervals of approximately 10 years [25]. Against this background of a randomly selected group of relatively inactive men and women, aspects have been evaluated in the body build of the highest level Polish athletes in tennis [17], pentathlon [15], dance [28], combat sports [16, 17, 14, 16, 22], and of world or European elite athletes engaged in a variety of sports [20]. In this study, we assess aspects of the body build of the Polish judo team against the current reference group, the students of the Warsaw University of Technology examined in 2011 as a new reference group. The last similar comparison of the somatotypes among Polish judo athletes, female [16, 22] and male [14, 20], was carried out in comparison with groups of students examined in 1972, 1984 and 1996 [25]. Research of the previous study 
indicated certain attributes in the body build of judo competitors compared with that of the average male population. The athletes were characterized by mesomorph body structure, with a robust skeleton (large magnitudes of knee and elbow breadths), well-developed muscles of legs (especially calf muscles), low body fatness, and very low ectomorphy, all compared to the average population, and of world or European elite athletes engaged in a variety of sports [14, $16,20,22])$. The current study allows tracking of possible changes in the structure of the body of highly trained athletes in this sport discipline. The judoists' somatotype analysis can provide better identification of the body build specification for athletes than can separate anthropometric characteristics, which strongly correlate with body height. The somatotype varies between different sports, between weight categories of competitors, and between those playing in different positions on the pitch, but has the smallest diversity among athletes practicing the same sport and employing the same techniques $[12,14,18,20]$. In our previous study we published the female reference group for comparison with athletes [23]. Now we have updated somatotype data from male non-athlete reference groups, complementing the comparative analysis applied in assessing the effects of the training process and selection.
The aim of this study was to determine the body composition and somatotype of untrained male students studying at Warsaw University of Technology in 2011, in order to create a current reference group for comparison, and to investigate the difference in body build between male judoists and untrained students of the University of Technology in Warsaw.

\section{Material and methods}

The study was approved by the Senate Ethics Committee of the Józef Piłsudski University of Physical Education in Warsaw. All participants were informed about the aim and the course of the study, and about the possibility of immediate withdrawal from the study without giving a cause. All subjects agreed to conditions that were presented in written form. The study was performed in accordance with the Declaration of Helsinki. Fifteen judoists (age 18.6 \pm 1.9 years, body height $177.4 \pm 8.5 \mathrm{~cm}$, body mass $80.3 \pm 15.8 \mathrm{~kg}$, BMI $25.3 \pm 3.4 \mathrm{~kg} \cdot \mathrm{m}^{-2}$, training experience $10.0 \pm 2.8$ years) and 154 untrained students in the first and second years of the Warsaw University of Technology (age $20.1 \pm 0.9$ years, body height $180.9 \pm 7.2 \mathrm{~cm}$,

Table 1. Anthropometrical characteristics (mean $\pm \mathrm{SD}$ ) of judoists and male students of Warsaw University of Technology (WUT)

\begin{tabular}{|c|c|c|c|c|c|}
\hline Variables & WUT, [n = 154] & Judoists, $[\mathrm{n}=15]$ & $\mathrm{Z}$ & $\mathrm{p}$ & Effect size (r) \\
\hline Age [years] & $20.1 \pm 0.9$ & $18.6 \pm 3.0$ & -1.85 & 0.063 & 0.143 \\
\hline Training [years] & - & $10.0 \pm 2.8$ & & & \\
\hline Body height $(\mathrm{B}-\mathrm{v})[\mathrm{cm}]$ & $180.86 \pm 7.15$ & $177.37 \pm 8.45$ & -1.63 & 0.104 & 0.125 \\
\hline Body mass $[\mathrm{kg}]$ & $75.58 \pm 10.93$ & $80.29 \pm 15.77$ & 1.22 & 0.223 & 0.094 \\
\hline BMI index $\left[\mathrm{kg} \cdot \mathrm{m}^{-2}\right]$ & $23.08 \pm 2.87$ & $25.32 \pm 3.43^{*}$ & 2.55 & 0.009 & 0.196 \\
\hline Wrist breadth $[\mathrm{cm}]$ & $5.77 \pm 0.33$ & $6.15 \pm 0.42^{*}$ & 2.95 & 0.003 & 0.227 \\
\hline Bicondylar femur breadth $[\mathrm{cm}]$ & $9.93 \pm 0.51$ & $9.93 \pm 0.62$ & 0.27 & 0.791 & 0.021 \\
\hline Bi-acromial breadth (a-a) $[\mathrm{cm}]$ & $40.77 \pm 1.85$ & $40.77 \pm 2.28$ & 0.30 & 0.765 & 0.023 \\
\hline Bi-cristal breadth (ic-ic) $[\mathrm{cm}]$ & $29.42 \pm 1.82$ & $28.34 \pm 1.56^{*}$ & -2.14 & 0.031 & 0.165 \\
\hline Arm girth flexed and tensed $[\mathrm{cm}]$ & $31.94 \pm 2.89$ & $34.81 \pm 3.77^{*}$ & 2.99 & 0.002 & 0.230 \\
\hline $\begin{array}{l}\text { Arm girth tensed corrected } \\
\text { by triceps skinfords }[\mathrm{cm}]\end{array}$ & $30.72 \pm 2.66$ & $34.05 \pm 3.81^{*}$ & 3.40 & $<0.001$ & 0.262 \\
\hline Calf girth $[\mathrm{cm}]$ & $38.33 \pm 2.75$ & $37.97 \pm 3.86$ & -0.36 & 0.720 & 0.028 \\
\hline Calf girth corrected by calf skinfold $[\mathrm{cm}]$ & $37.18 \pm 2.48$ & $37.10 \pm 3.72$ & -0.23 & 0.816 & 0.018 \\
\hline$\Sigma 3 \mathrm{SKF}[\mathrm{cm}]$ & $42.0 \pm 18.75$ & $33.06 \pm 8.25$ & -1.66 & 0.097 & 0.128 \\
\hline$\Sigma 3 \mathrm{SKF}$ corrected $[\mathrm{mm}]$ & $39.60 \pm 17.81$ & $31.68 \pm 7.56$ & -1.37 & 0.09 & 0.171 \\
\hline Endomorphy & $3.90 \pm 1.56$ & $3.21 \pm 0.78$ & -1.48 & 0.139 & 0.114 \\
\hline Mezomorphy & $4.60 \pm 1.14$ & $5.87 \pm 1.16^{*}$ & 3.56 & $<0.001$ & 0.274 \\
\hline Ektomorphy & $2.88 \pm 1.27$ & $1.83 \pm 0.96^{*}$ & -3.23 & $<0.001$ & 0.249 \\
\hline
\end{tabular}

* - mean differ significantly with respect to WUT, $\mathrm{p}<0.05$. 
body mass $75.6 \pm 10.9 \mathrm{~kg}$, BMI $23.1 \pm 2.9 \mathrm{~kg} \cdot \mathrm{m}^{-2}$ ) participated in the study during November and December 2011 (Table 1). For the sake of the study, the competitors were divided into three prearranged weight categories: Group 1 light $(\mathrm{n}=4)$; Group 2 medium $(\mathrm{n}=6)$; Group 3 heavy $(\mathrm{n}=5)$. Thus, Group 1 combines three categories (up to $60 \mathrm{~kg}$, over $60 \mathrm{~kg}$ to $66 \mathrm{~kg}$, over $66 \mathrm{~kg}$ to $73 \mathrm{~kg}$ ), Group 2 combines two (over $73 \mathrm{~kg}$ to $81 \mathrm{~kg}$, over $81 \mathrm{~kg}$ to $90 \mathrm{~kg}$ ), and Group 3 combines two (over $90 \mathrm{~kg}$ to $100 \mathrm{~kg}$, over $100 \mathrm{~kg}$ ) [14, 18]. The research group of male students from the Warsaw University of Technology was randomly selected according to the methodology used since the 1960 s as a reference group for comparison particularly of body building athletes. The male students from the Warsaw University of Technology were drawn from students of all faculties as follows: names were drawn from lists of individual faculties, the number of respondents from each faculty was proportional to the participation of students in the faculty compared to the total number of students in the given year of study, the students selected were not practicing any sport professionally, and all the students had Polish nationality and were Caucasians.

Anthropometric examinations considered the following variables: height and body mass, six skinfolds (triceps, biceps, subscapular, supraspinale, medial-calf, abdominal), arm girth relax and tensed (with forearm flexed at $90^{\circ}$ and with biceps tensed), girths (waist, hip and calf), breadths of (wrist, bicondylar humerus and femur, biacromial and bicristal diameters).

Body height was determined using a SiberHegner anthropometer (Switzerland), skinfolds were measured using a Harpenden skinfold caliper, girth measurements were acquired with a steel measuring tape, and wrist girth and bicondylar diameters of the femur and humerus were measured using a small spreading caliper (SiberHegner, Switzerland). Measurements of body mass and body composition were carried out using a Model TBF-300 body composition analyzer (Tanita, Japan) adjusted for
STANDARD. Body composition by use of the anthropometric method was estimated by Piechaczek's method [24]. Total body fat $\mathrm{F}(\mathrm{kg}, \%)$ and total lean body mass LBM (kg, \%) were then calculated. All measurements were taken by the same investigator, applying standard anthropometric methods according to the procedure of the International Biological Program [30]. BMI and WHR (waist/hip ratio) indexes were calculated and corrected by skinfolds, arm girth (tensed and corrected by triceps and biceps skinfolds) and calf girth (corrected by calf skinfold).

Somatotype was calculated by the Heath-Carter method. Endomorphy was calculated based on the sum of three skinfolds (triceps, subscapular, supraspinale ) $\Sigma 3 S K F[\mathrm{~cm}]$ and corrected for height in $\mathrm{cm} \Sigma$ SSKFcorrected [mm] [3].

The measurements were conducted at the turn of November and December 2011. All measurements were performed in the morning.

\section{Statistical analysis}

Significant differences between groups were assessed using the Mann-Whitney test. The effect size was assessed by $r=|Z| / \sqrt{N}$, where $N$ is a total number of the subjects. The following interpretation was adopted $0.1 \leq \mathrm{r}<0.3$ small, $0.3 \leq \mathrm{r}<0.5$ medium, and $\mathrm{r} \geq 0.5$ large [5]. The level of statistical significance was set at $\alpha=0.05$. All statistical calculations were performed using Statistica program (v. 12, StatSoft).

\section{Results}

The participants in the two groups had similar heights (Table 1). However, the BMI values were significantly higher in the competitors $(p<0.05)$. The examined athletes were characterized by mesomorph body structure with a robust skeleton. Significant differences $(p<0.05)$ between the groups were found in the wrist and bicristal breadth,

Table 2. Skinfold thickness (mean \pm SD): comparison between judoists and male students of Warsaw University of Technology (WUT)

\begin{tabular}{lccccc}
\hline Variables & WUT, $[\mathrm{n}=154]$ & Judoists, $[\mathrm{n}=15]$ & $\mathrm{Z}$ & $\mathrm{p}$ & Effect size $(\mathrm{r})$ \\
\hline Triceps skinfold [cm] & $1.22 \pm 0.54$ & $0.77 \pm 0.35^{*}$ & -3.70 & $<0.001$ & 0.285 \\
Axilla skinfold [cm] & $1.14 \pm 0.63$ & $0.83 \pm 0.25$ & -1.74 & 0.082 & 0.134 \\
Subscapular skinfold [cm] & $1.33 \pm 0.66$ & $1.03 \pm 0.24$ & -1.84 & 0.066 & 0.141 \\
Supraspinale skinfold [cm] & $1.65 \pm 0.84$ & $1.51 \pm 0.41$ & 0.09 & 0.924 & 0.007 \\
Medial-calf skinfold [cm] & $1.15 \pm 0.60$ & $0.87 \pm 0.34$ & -1.61 & 0.108 & 0.124 \\
Abdominal skinfold [cm] & $1.79 \pm 0.89$ & $1.31 \pm 0.56$ & -1.93 & 0.052 & 0.149 \\
Sum of 6 skinfolds [cm] & $8.27 \pm 3.70$ & $6.32 \pm 1.81^{*}$ & -1.98 & 0.047 & 0.152 \\
\hline
\end{tabular}

* - mean differ significantly with respect to WUT, $\mathrm{p}<0.05$. 
Table 3. Body tissue composition ( $m e a n \pm S D$ ) of judoists and male students of Warsaw University of Technology (WUT)

\begin{tabular}{lccccc}
\hline Variables & WUT, $[\mathrm{n}=154]$ & Judoists, $[\mathrm{n}=15]$ & $\mathrm{Z}$ & $\mathrm{p}$ & Effect size $(\mathrm{r})$ \\
\hline Body mass $[\mathrm{kg}]$ & $75.58 \pm 10.93$ & $80.29 \pm 15.77$ & 1.22 & 0.223 & 0.094 \\
$\mathrm{FAT}_{\text {BIA }}[\%]$ & $13.26 \pm 4.43$ & $10.57 \pm 3.80^{*}$ & -2.28 & 0.022 & 0.175 \\
$\mathrm{FAT}_{\mathrm{BIA}}[\mathrm{kg}]$ & $10.39 \pm 4.84$ & $8.77 \pm 4.29$ & -1.25 & 0.213 & 0.096 \\
$\mathrm{FFM}_{\mathrm{BIA}}[\mathrm{kg}]$ & $65.19 \pm 7.06$ & $71.52 \pm 12.96^{*}$ & 4.94 & $<0.001$ & 0.380 \\
$\mathrm{FAT}_{\text {ANT }}[\%]$ & $17.07 \pm 2.97$ & $14.81 \pm 2.15^{*}$ & -2.99 & 0.002 & 0.230 \\
$\mathrm{FAT}_{\text {ANT }}[\mathrm{kg}]$ & $13.10 \pm 3.82$ & $11.96 \pm 3.21$ & -1.00 & 0.322 & 0.077 \\
$\mathrm{FFM}_{\text {ANT }}[\mathrm{kg}]$ & $62.49 \pm 7.84$ & $68.33 \pm 13.22^{*}$ & 1.64 & 0.102 & 0.126 \\
\hline
\end{tabular}

ANT - the anthropometric method; variable calculated by Piechaczek's formula [26]; BIA - variables measured by bioelectrical impedance analysis; * - mean differ significantly with respect to WUT, $\mathrm{p}<0.05$.

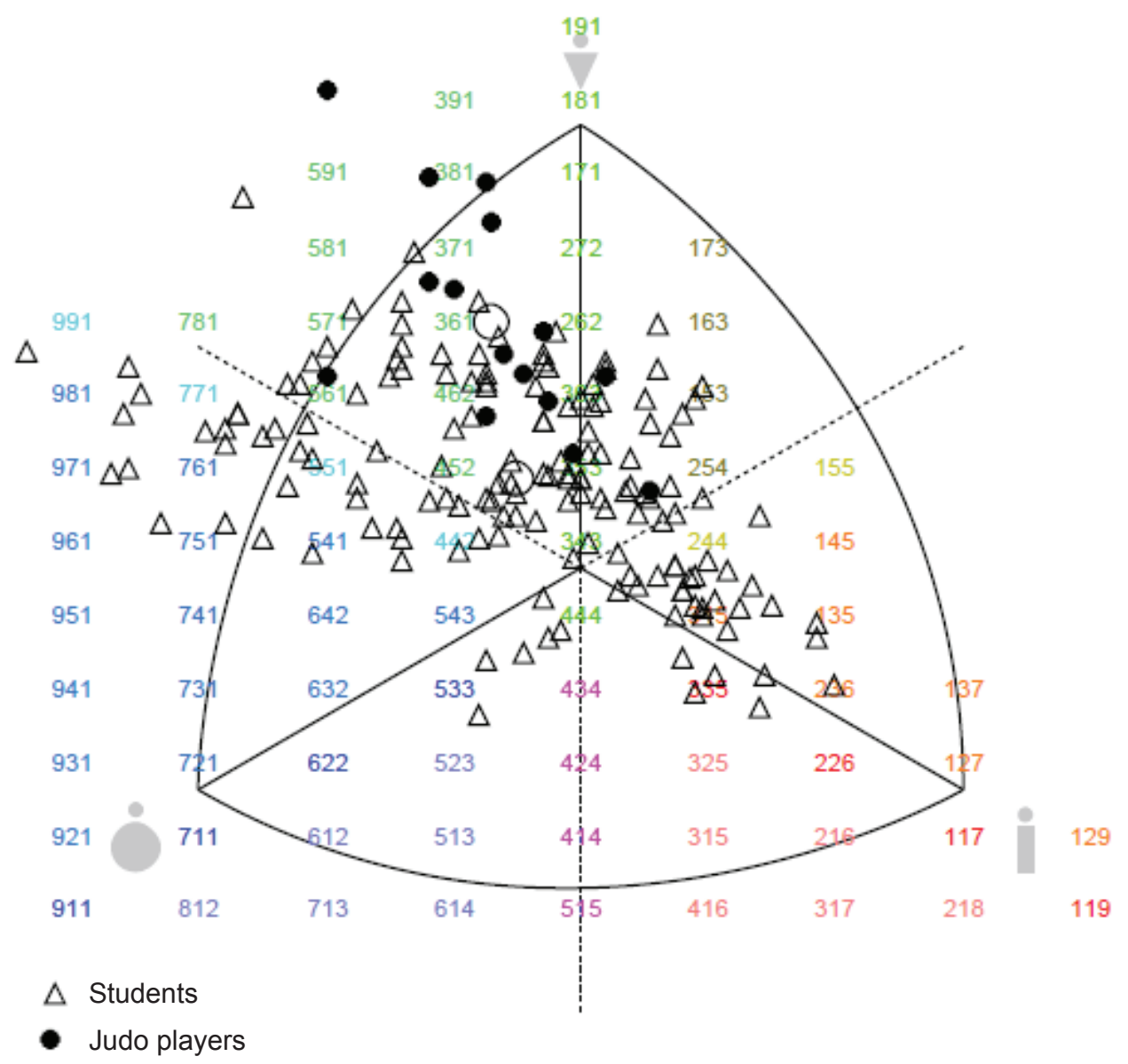

Fig. 1. Somatochart of the judoists $(n=15)$ and male students of Warsaw University of Technology measured $1(n=154)$. The circles indicate the mean values of somatotype

in arm tensed circumference as well as this circumference corrected by triceps skinfolds (indicators of muscle mass). The groups were also significantly different $(p<0.05)$ in the amount of subcutaneous fat assessed by skinfold thickness (Table 2) and in total body composition (FAT [\%],
FFM [kg]) as estimated by BIA and anthropometric methods (Table 3). The mean somatotype of the judo athletes was: 3.25 .91 .8 (values for endomorphy $3.2 \pm 0.8$, mesomorphy $5.9 \pm 1.2$ and ectomorphy $1.8 \pm 1.0$, respectively). Spread of somatotypes was very large on the somatochart, 
due to the diversity of body build in judoists belonging to three different weight categories. The largest diversity was recorded in the ectomorphy component (range from 0.1 to 3.6) and mesomorphy (range from 4.1 to 8.6 ).

The lowest ectomorphy and highest mesomorphy were characteristic for heavy weight category judoists (over $90 \mathrm{~kg}$ ). The mean somatotype in this weight group was 3.47.10.9 (3.40 $\pm 0.68 ; 7.12 \pm 0.89 ; 0.94 \pm 0.59)$. The highest ectomorphy and the lowest endomorphy and mesomorphy were characteristic for light weight category competitors (over $60 \mathrm{~kg}$ to $73 \mathrm{~kg}$ ), with an average somatotype of 2.84.82.8 (2.80 $\pm 0.78 ; 4.80 \pm 0.51 ; 2.78 \pm 0.79)$. This group was found to have similar characteristics in terms of somatotype components. The mean values of the components of body build in the middle weight category judoists was 3.35.51.9 (3.33 $\pm 1.03 ; 5.53 \pm 0.60 ; 1.90 \pm 0.64)$, this being between the previously mentioned categories of judo athletes. Differentiation of the endomorphy component was also very large (range from 2.2 to 5.1 respectively). The mean somatotype of the untrained students was: 3.94.62.9 (values for endomorphy $3.9 \pm 1.6$, mesomorphy $4.6 \pm 1.1$, and ectomorphy $2.9 \pm 1.3$ ), characterizing little participation of mesomorphy and ectomorphy, with a significant difference $(p<0.05)$ in the body build of the judo athletes compared with the non-athletes (Fig. 1). Differentiation of the endomorphy, mesomorphy and ectomorphy components was very large (ranges of 1.78.8, 3.08.1 and 0.16 .0 , respectively).

\section{Discussion}

Success in judo requires a high level of physical and performance preparation $[8,9,18,21]$. The planning of judo training should not only concern the applied training loads, but it should also focus on the athletes' physical abilities. Research of the body build of judo athletes has indicated those anthropometric attributes that are required in this sport. Following from the study of somatotype of athletes representing various sports, wrestlers and judoists were the most robustly built, with the highest level of mesomorphy and a very low level of ectomorphy [20]. Research of JiWoong et al. [18] on 40 elite judo athletes showed that these athletes were mainly meso-endomorphs and indicated that the higher the weight category, the more endomorphic was the somatotype. However, somatotype distribution of world class judoists in weight categories was very homogeneous. Comparing results of different authors studying the physique of judoists, it can be concluded that with increasing level of competitors in the sport, the value of mesomorphy increases, whilst the value of endomorphy decreases $[9,14,18]$. Motor skills, strength and power are important elements of physical performance in judo, and these are closely related to the anthropometric variables. The studies by Lewandowska et al. [21] on Polish judo players indicated that the values of mesomorphic somatotype components influenced muscle torque and power output. Competitors with higher levels of mesomorphy can develop greater acceleration and overcome greater external resistance. This factor may have a substantial influence on the effectiveness of a judo fight [14]. Judoists in our study had a similar contribution of components in body build (3.25.91.8) as did the Polish judo athletes (2.85.71.5) selected for Sydney 2000 [20], as well as for the national team examined in 2013, in which the assessment of internal proportions of the body build was achieved by Perkal's natural indicators [14]. Polish high level judoists are not inferior in somatotype to elite Spanish (4.94.61.2) [9] or Korean (2.35.01.1) judo competitors [18]. Male athletes examined by us even had high values of mesomorphy in body composition with a similar mean body height $(177.4 \pm 8.5 \mathrm{~cm} ; 176.7 \pm 6.7 \mathrm{~cm} ; 175.5 \pm 7.2 \mathrm{~cm}$, respectively). The somatic profile of body build for players in this sport seems to be optimal for achieving high results, because the mean somatic features of Polish elite judo athletes selected by the Heath-Carter method has not changed since the 1990s. The same height $(177.5 \pm 9.2 \mathrm{~cm})$, similar characteristics of the skeleton (bicondylar femur $10.12 \pm 0.61 \mathrm{~cm}$ and humerus $7.28 \pm 0.44 \mathrm{~cm}$ ) and the body circumference (arm $33.8 \pm 3.3 \mathrm{~cm}$ and calf girths $38.8 \pm 2.8 \mathrm{~cm}$ ) of the judo competitors qualifying for the Olympic Games in Sydney [20] compared well to our results $(177.4 \pm 8.5 \mathrm{~cm} ; 9.93 \pm 0.62 \mathrm{~cm} ; 7.28 \pm 0.43 \mathrm{~cm}$; $34.05 \pm 3.81 \mathrm{~cm} ; 37.10 \pm 3.72 \mathrm{~cm})$. The difference in morphological build of athletes according to weight category was also confirmed by our research. The body build found in athletes in light, medium and heavy groups was similar to the natural indicators of somatic profiles of competitors in the Jagiełło [14] study. As judo athletes fell into a higher weight group, so the value of the endomorphic component was higher and the value of the ectomorphy component was lower, with this division into weight groups bringing together judoists with similar somatotypes to those indicated by the physique of the Korean judoists in relation to their weight category [18].

On the other hand, investigations of top Polish judo players and untrained students conducted by different authors $[14,20]$ found that the FAT estimated by the anthropometric method [24] of the competitors (11.214.7\%) was lower than for the control group (14.4\%-15.7\%). In our study, the judo group differed significantly from the control group (students of the Warsaw University of Technology 2011) in terms of body fat $(14.8 \%, 17.1 \%$, respectively). This result can be seen in other studies which compare Korean elite male judo athletes with Korean nonathletes [18]. 


\section{Conclusions}

The morphological characteristics of judo athletes stand out from the untrained men with far better developed muscular systems and a smaller share of total fat in body composition. Judoists have higher mesomorphic component values and lower endomorphic and ectomorphic component values in the somatotype than the non-athlete comparison group. As judo athletes fall into a higher weight group, so the value of the endomorphic component is higher and the value of the ectomorphic component is lower, with this division into weight groups bringing together judoists with similar somatotypes. The somatic profile of body build of athletes in this sport seems to be optimal for achieving high results, because the somatotype selected has not changed since the 1990s. The data from this study provide in part the physical characteristics of elite judo athletes and those of a control reference group, allowing comparison of aspects of the body build of athletes in this and other sports.

Conflict of interest: Authors state no conflict of interest.

\section{References}

1. Buśko K., Lipińska M., Michalski R., Pastuszak A. (2013) Somatotypevariables related to muscle torque and power output in female volleyball players. Acta Bioeng. Biomech., 15(2): 119-126.

2. Carter J.E.L., Ackland T.R., Kerr D.A., StapffA.B. (2005) Somatotype and size of elite female basketball players. J. Sports Sci., 23(10): 1057-1063.

3. Carter J.E.L. (2002) Part 1: The Heath-Carter Anthropometric Somatotype-Instruction Manual. Available at: http://www.somatotype. org/Heath-CarterManual.pdf

4. Carvajal W., Betancourt H., León S., Deturnel Y., Martínez M., Echevarría I., Castillo M.E., Serviat N. (2012) Kinanthropometric profile of Cuban women Olympic volleyball champions. MEDICC review 14(2): 16-22.

5. Cohen J. (2013) Statistical power analysis for the behavioral sciences. Academic press.

6. Diafas V., Dimakopoulou E., Diamanti V., Zelioti D., Kaloupsis S. (2011) Anthropometric characteristics and somatotype of Greek male and female flatwater kayak athletes. Biomed. Hum. Kinet., 3: 111-114.

7. Ferragut C., Abraldes J.A., Vila H., Rodríguez N., Argudo F.M., Fernandes R.J. (2011) Anthropometry and throwing velocity in elite water polo by specific playing positions. J. Hum. Kinet., 27(1): 31-44.

8. Franchini E., Takito M.Y., Kiss M.A.P.D.M., Sterkowicz S. (2005) Physical fitness and anthropometrical dif- ferences between elite and nonelite judo players. Biol. Sport, 22(4): 315-328.

9. Francini E., Huertas J.R., Sterkowicz S., Carratala V., Gutiérrez-García C., Escobar-Molina R. (2011) Anthropometrical profile of elite Spanish judoka: comparative analysis among ages. Arch. Budo, 7(4): 239-245.

10. Gutnik B., Zuoza A., Zuozienè I., Alekrinskis A., Nash D., Scherbina S. (2015) Body physique and dominant somatotype in elite and lowprofile athletes with different specializations. Medicina, 51: 247-252.

11. Hazir T. (2010) Physical characteristics and somatotype of soccer players according to playing level and position. J. Hum. Kinet., 26: 83-95.

12. Heath H.B., Carter J.E.L. (1967) A modified somatotype method. Am. J. Phys. Anthropol., 27: 57-74.

13. Jagiello M., Jagiello W. (2009) Internal proportions of the body composition in members of the female national tennis team of Poland. Education. Physical Training. Sport. 2(73): 28-34.

14. Jagiełło W. (2013) Differentiation of the body build in judo competitors of the men's Polish national team. Arch. Budo, 9(2): 117-125.

15. Jagiełło W., Kalina R., Jagiełło M. (2011) Differentiation of the body composition in the Polish national team pentathletes. Bal. J. Health Phys. Activ., 3(2): 105-111.

16. Jagiello W., Kalina R.M., Korobielnikow G. (2007) Morphological diversification of female judo athletes. Arch. Budo, 3(1): 27-34.

17. Jagiełło W., Kruszewski A. (2009) Morphological diversification of competitors training GrecoRoman style of wrestling. Arch. Budo, 5(1): 147-153.

18. JiWoong Noh, JuHyun Kim, Junghwan Kim (2014) Somatotype Analysis of Elite Judo Athletes Compared with Nonathletes for Health Science Research. Toxicol. Environ. Health Sci., 6(2): 99-105.

19. Kołodziej H., Lipowicz A., Szklarska A., Bielicki T. (2015) Secular trends in body height and body mass in 19-year-old Polish men based on six national surveys from 1965 to 2010. Am. J. Hum. Biol., 27(5): 704-709.

20. Krawczyk B., Skład M., Jackiewicz A. (1997) HeathCarter somatotypes of athletes representing various sports. Biol. Sport, 14(4): 305-310.

21. Lewandowska J., Buśko K., Pastuszak A., Boguszewska K. (2011) Somatotype variables related to muscle torque and power in judoists. J. Hum. Kinet., 30: 5-12.

22. Obuchowicz-Fidelus B., Marchocka M., Majle B., Dąbrowska A., Wojczuk J., Furdal S., Lukaszewska J. (1986) Antrhropometric, strenght and power characteristics of female kayak and judo athletes. Biol. Sport, 3(1): 5-17.

23. Pastuszak A., Buśko K., Kalka E. (2016) Somatotype and body composition of volleyball players and untrained female students - reference group for comparison in sport. Anthropol. Rev., 79(4): 461-470. 
24. Piechaczek H. (1976) Estimation of total body fat by densitometric and anthropometric methods. Stud. Phys. Anthropol., 2: 33-45.

25. Piechaczek H., Lewandowska J., Orlicz B. (1996) Zmiany w budowie ciała młodzieży akademickiej Politechniki Warszawskiej w okresie 35 lat [in Polish]. Wych. Fiz. Sport, 40(3): 3-14.

26. Pieter W., Bercades L.T. (2009) Somatotypes of national elite combative sport athletes. Braz. J. Biomotricity, 3(1): 21-30.

27. Pietraszewska J., Burdukiewicz A., Strachoń A., Andrzejewska J., Pietraszewski B. (2015) Anthropometric characteristics and lower limb power of professional female volleyball players. S. Afr. J. Res. Sport Phys. Educ. Recreation, 37(1): 99-112.

28. Pilewska W., Pilewski R., Zukow W. (2013) Characteristics of body composition highly qualified dancers and dancers Latin American style of dance sports in light of Perkal method. J. Health Sci., 3(8): 193-218.

29. Tanner J.M. (1964) The physique of the Olympic athletes. George Allen and Unwin Ltd., London.
30. Weiner J.S., Lourie J.A. (1969) Human Biology, a Gide to Field Methods. International Biological Programme. Blackwell Scientific Publications, Oxford and Edinburgh.

31. Zia-Ul-Haq M., Low Fook Lee J., Bin Dasril B., Kuan Boon O., Saleem M. (2016) Morphological characteristics of malaysian national cricket batsmen. Int. J. Physiother., 3(1): 58-65.

\section{Received 09.01.2017 \\ Accepted 15.02.2017}

(C) University of Physical Education, Warsaw, Poland

\section{Acknowledgments}

The study was supported by the Ministry of Science and Higher Education (Grants No. AWF: DS.-134 and DS.-145). 